\title{
O umundurowaniu urzędników administracji ogólnej w Polsce międzywojennej
}

\author{
Abstract \\ Concerning Uniforms for Officials of the General Administration in Interwar \\ Poland
}

The interwar period brought with it a wider interest in the question of uniforms, especially in the context of services acting in the interests of public order and safety. Uniforms for civilian clerks received less attention. The first attempts to introduce uniforms for civil clerks were taken by the temporary administration in the Eastern Borderlands. The move came about as an effort at building respect for Polish government officials among the local people, above all, members of the national minorities, in consideration of the frequent contact between the clerks and the military. In central Poland, where the positions of the first starostas were filled by representatives of the local elites, the introduction of separate uniforms served to show the difference between governmental officials (including local) and civil society. The civil service law of 1922 aimed to settle the question of uniforms. It allowed for the introduction of separate uniforms for clerks, but left the details to subsequent regulation. As a result, regulations governing civil clerks' uniforms (e.g. railwaymen, customs officials, diplomats, etc.) were left to successive administrations. Talk of uniforms for clerks in the general administration continued, though up until the end of the Second Republic the problem remained unsolved. Among the biggest problems was a lack of money, whether in the state budget or the clerks' own pockets.

Keywords: general administration, history of the public administration, Second Polish Republic, uniforms.

Słowa klucze: administracja ogólna, historia administracji, II Rzeczpospolita, umundurowanie.

Zagadnienie umundurowania w II Rzeczypospolitej nie jest problemem całkowicie nowym, w powszechnej świadomości wiąże się ono jednak przede wszystkim ze strukturami odpowiedzialnymi za porządek i bezpieczeństwo, czyli z wojskiem oraz policją. Ten punkt widzenia znajduje odzwierciedlenie także w stosunkowo obfitej literaturze 
przedmiotu odnoszącej się właśnie do polskiej armii ${ }^{1}$. Dużym powodzeniem cieszyło się również zagadnienie umundurowania międzywojennych Policji Państwowej i Policji Województwa Śląskiego ${ }^{2}$. Analiza problematyki umundurowania służb wykraczająca poza wymienione była przedmiotem opracowań już zdecydowanie rzadziej. W tym kontekście najczęściej omówieniu podlegały te ich rodzaje, które w powszechnym odbiorze kojarzyły się z uniformami. Do kategorii tej możemy zaliczyć podległe ministrowi skarbu Straż Celną oraz Straż Graniczną czy inną formację odpowiedzialną za ochronę w zasadzie wschodniej granicy - Korpus Ochrony Pogranicza (podległy ministrowi spraw wewnętrznych) ${ }^{3}$. Przedmiotem zainteresowania było również umundurowanie i uzbrojenie podległej ministrowi sprawiedliwości straży więziennej II RP ${ }^{4}$. Zdecydowanie słabiej rozpoznano zagadnienia związane $\mathrm{z}$ umundurowaniem międzywojennych urzędników państwowych, a problem ten w odniesieniu do administracji ogólnej był w dotychczasowej literaturze przedmiotu jedynie sygnalizowany, stąd wydaje się, że warto się nad nim chwilę zatrzymać 5 .

Należy w tym miejscu zauważyć, że omawiane zagadnienie mieści się także w szerszym kontekście zabytków będących obiektem zainteresowania archeologii prawnej, a mających uzmysławiać ,instytucje, stosunki i czynności prawne”6. Na ziemiach polskich dopiero wiek XIX przyniósł de facto pojawienie się umundurowania dla urzędników cywilnych (choć jego geneza sięgała, zdaniem Witolda Maisla, przedrozbiorowych mundurów wojewódzkich). W tym zakresie dość rozbudowane przepisy i - dodajmy - obejmujące stosunkowo szerokie grono funkcjonariuszy, obowiązywały na terenie Królestwa Polskiego. Już wówczas rozdzielano mundury galowe i codzienne. W zakresie kolorystyki odchodziły one od tradycji np. Księstwa Warszawskiego - w miejsce barw narodowych, granatu z elementami czerwieni i karmazynu, wprowadzono ciemnozielone uniformy. Co ciekawe, również wówczas jako element wyposażenia pojawiały

1 Na przykład: H. Wielecki, Polski mundur wojskowy 1918-1939, Warszawa 1995; M. Rezler, Mundur wielkopolski w latach 1918-1919, Kościan 1973; H. Kroczyński, Mundur Armii Wielkopolskiej. Ze zbiorów Muzeum Oręża Polskiego w Kolobrzegu, Kołobrzeg 2008; A. Smoliński, Mundur i barwy jazdy dywizyjnej i strzelców konnych Wojska Polskiego. Lata 1919-1939, Grajewo 2012; W. Lietz, Umundurowanie lekarzy weterynarii w latach 1914-1939 [w:] Wybitni lekarze weterynaryjni na przestrzeni dziejów w świecie $i$ w Polsce. Historia zawodu lekarsko-weterynaryjnego, zainteresowania pozazawodowe lekarzy weterynaryjnych, Sesja naukowa z udziałem gości zagranicznych, Wrocław-Kobyla Góra, 20-22 czerwca 2003, oprac. J. Króliński, s. 68-74 (dotyczy wyłącznie lekarzy weterynarii w WP).

2 A. Kostankiewicz, Umundurowanie i uzbrojenie Policji Państwowej 1919-1939, „Zeszyt Naukowy Muzeum Wojska” 2000, nr 13, s. 82-93; R. Litwiński, Korpus Policji w II Rzeczypospolitej. Stużba i życie prywatne, Lublin 2010, s. 257-269, 557-564.

3 A. Skorek, Umundurowanie funkcjonariuszy Straży Celnej (1926), „Grot - zeszyty historyczne poświęcone historii wojska i walk o niepodległość” 2003, nr 16, s. 37-45; A. Kostankiewicz, Umundurowanie i uzbrojenie polskiej Straży Granicznej (1928-1939), „Studia do dziejów dawnego uzbrojenia i ubioru wojskowego" 2011, cz. XIII, s. 181-215; J. Rutkiewicz, Umundurowanie KOP [w:] J. Prochwicz, A. Kostankiewicz, J. Rutkiewicz, Korpus Ochrony Pogranicza 1924-1939, Warszawa 2006, s. 125-135, tab. I-VIII.

4 A. Kostankiewicz, Umundurowanie i uzbrojenie Straży Więziennej II RP (1924-1939) [w:] Z dziejów więzienia w Lublinie, red. T. Radzik, Lublin 2007, s. 133-142; K. Pawlak, Więziennictwo polskie w latach 1918-1939, Kalisz 1995, s. 26-28.

5 J. Mierzwa, Starostowie Polski międzywojennej. Portret zbiorowy, Kraków 2012, s. 350-351.

6 W. Maisel, Archeologia prawna Polski, Warszawa-Poznań 1982, s. 20. 
się szpady czy kapelusze. Do doświadczeń tych i tradycji odwoływano się w okresie II Rzeczypospolitej ${ }^{7}$.

W okresie walk o granice władze zdecydowały się na wprowadzenie umundurowania dla urzędników Zarządu Cywilnego Ziem Wschodnich (ZCZW). Źródeł tej decyzji należy upatrywać w specyfice służby w administracji tymczasowej na Kresach. Zarząd był bowiem jednostką powołaną 8 lutego 1919 r. przez Naczelnika Państwa dla przejściowego zorganizowania obszarów stanowiących bezpośrednie zaplecze rodzącego się frontu polsko-bolszewickiego. Abstrahując od motywacji politycznej przyświecającej Piłsudskiemu, a związanej z chęcią wyzyskania ZCZW dla realizacji lansowanej przezeń koncepcji federacyjnej, administracja ta miała swoją specyfikę: stojący na czele Komisarz Generalny działał najpierw z ramienia, a następnie przy Naczelnym Dowództwie Wojsk Polskich. Reprezentował je we wszystkich sprawach zarządu cywilnego na podległym terenie $^{8}$ oraz był powoływany i odwoływany przez Naczelnego Wodza ${ }^{9}$. A zatem zarówno w wymiarze służbowej podległości, jak i w związku z codziennym urzędowaniem nieodłącznym elementem służby w ZCZW był nader częsty kontakt z armią (dodajmy, wielokrotnie mający charakter sporu). Tym samym przyznanie urzędnikom Zarządu prawa do noszenia munduru polowego było elementem budowania ich autorytetu w stosunku do społeczeństwa, ale miało także ułatwiać relacje $\mathrm{z}$ armią.

Motywację taką zawierał rozkaz Naczelnego Wodza z 13 maja 1919 r., na mocy którego przyznano urzędnikom ZCZW prawo do noszenia munduru polowego, jak również możliwość korzystania z wszystkich uprawnień przysługujących oficerom służby czynnej, łącznie $z$ oddawaniem honorów ${ }^{10}$. Tak szerokie przywileje stały się szybko przyczyną nieporozumień między administracją a wojskiem, dlatego w październiku 1919 r. zrezygnowano z naramienników, a także odebrano funkcjonariuszom Zarządu prawo do noszenia broni białej. Ostateczne rozstrzygnięcie dotyczące wzoru munduru pozostawiono zarządzeniu Komisarza Generalnego Ziem Wschodnich, które zresztą ten wydał 20 października 1919 r. Zgodnie z nim urzędnikom ZCZW przysługiwało prawo noszenia

[...] uniformu kroju wojskowego typu frencz ${ }^{11} \mathrm{z}$ szarego lub brunatnego materiału z guzikami złotymi z orzełkiem; spodnie koloru munduru lub czarne z wąską amarantową wypustką; czapka z amarantową wypustką, złotym orzełkiem, złotym słońcem i paskiem, płaszcz szary kroju wojskowego ze złotymi guzikami i orzełkiem ${ }^{12}$.

Funkcjonariusz mógł nosić jako broń przyboczną jedynie rewolwer na pasie, a czapkę mundurową mógł mieć na sobie, również będąc w ubraniu cywilnym. Zarządzenie regulowało także specjalne zróżnicowanie odznak w zależności od stanowiska, a w isto-

7 Ibidem, s. 210-213.

8 Zrazu poza wschodnimi granicami byłego Królestwa Polskiego, z wyjątkiem powiatów białostockiego, sokólskiego i bielskiego.

9 J. Gierowska-Kałłaur, Zarząd Cywilny Ziem Wschodnich (19 lutego 1919 - 9 września 1920), Warszawa 2003, s. 68-75.

10 Dziennik Urzędowy Zarządu Cywilnego Ziem Wschodnich (dalej: Dz.U.Z.C.Z.W.) z 1919 r. Nr 3, poz. 16.

11 Frencz - (za: Słownik Języka Polskiego) kurtka typu wojskowego z klapami i czterema kieszeniami.

12 Dz.U.Z.C.Z.W. z 1919 r. Nr 23, poz. 236. 
cie - od stopnia służbowego ${ }^{13}$. Ten stan rzeczy obowiązywał na terenie administracji ZCZW do końca jej istnienia ${ }^{14}$. Powołany po polskiej kontrofensywie na terenach kresowych na podstawie rozkazu Naczelnego Wodza z 9 września 1920 r. Zarząd Terenów Przyfrontowych i Etapowych (ZTPiE) był typową administracją tymczasową uzależnioną od MSW w większym stopniu, niż $\mathrm{ZCZW}^{15}$. Niemniej na terenie jej funkcjonowania utrzymano dotychczasowe regulacje, w tym także i te dotyczące umundurowania urzędników. Doprecyzowano jedynie, z którymi stanowiskami w zarządzie związane jest uprawnienie do noszenia munduru, a także przyznano jednorazowe świadczenie mundurowe ${ }^{16}$.

Warto zauważyć, że element ścisłego kontaktu z wojskiem i związana z tym potrzeba wzmocnienia autorytetu urzędnika cywilnego powodowały, iż umundurowaniem obdarzono nie tylko funkcjonariuszy na Kresach Wschodnich, ale także komisarzy cywilnych służących przy dowództwach grup operujących przy granicy zachodniej. Jego wygląd był zbliżony do tego obowiązującego na Kresach ${ }^{17}$.

Zarówno w odniesieniu do Kresów Wschodnich, jak i do pogranicza polsko-niemieckiego mamy do czynienia z sytuacją ekstraordynaryjną, związaną ze stałym i bezpośrednim kontaktem $\mathrm{z}$ armią, co implikowało konieczność podniesienia autorytetu urzędników m.in. przez ich umundurowanie. Jak sytuacja zatem kształtowała się na obszarach, gdzie te uwarunkowania nie występowały? Na konieczność umundurowania urzędników państwowych zwracano uwagę jeszcze przed odzyskaniem przez Polskę suwerenności, ale dyskusja ta dotyczyła przede wszystkim funkcjonariuszy niższych, głównie woźnych i gońców ${ }^{18}$.

Kwestia ta stała się jednak paląca w odniesieniu do komisarzy ludowych ${ }^{19}$ powoływanych w pierwszych tygodniach niepodległości. Często nie byli to zawodowi urzędnicy, a raczej reprezentanci miejscowych elit politycznych czy społecznych. Obejmowali oni stanowisko na skutek presji społeczności lokalnych, brakowało zatem symbolu rodzącej się państwowości, którą reprezentowali. Oczywiście ze względu na to, że potrzeba ta pojawiła się nagle, nie mogło być mowy o standaryzacji uniformów. Postawiono raczej na dodatki mogące być wyróżnikiem i odwołujące się do wzorców dziewiętnastowiecznych. Należała do nich np. komisarska szarfa, biało-amarantowa, z metalowym orłem w koronie, wykorzystywana przez komisarza ludowego w Radomiu podczas uroczystych czynności urzędowych (wybory) ${ }^{20}$. Brak ujednolicenia zasad w tym zakresie po-

13 Dz.U.Z.C.Z.W. z 1919 r. Nr 22, poz. 226; Nr 23, poz. 236.

14 J. Gierowska-Kałłaur, Zarząd..., s. 98-100.

15 W. Kozyra, Polityka administracyjna władz polskich na Ziemiach Wschodnich Rzeczypospolitej Polskiej w latach 1918-1926, „Annales UMCS. Sec. F (Historia)” 2005, t. LIX, s. 422.

16 Dziennik Urzędowy Zarządu Terenów Przyfrontowych i Etapowych (dalej: Dz.U.Z.T.P.E.) z 1920 r. Nr 1, poz. 4; Nr 2, poz. 12.

${ }_{17}$ Archiwum Państwowe w Kielcach (dalej: AP Kielce), Urząd Wojewódzki Kielecki, sygn. 2264, s. 54-55.

18 Archiwum Akt Nowych w Warszawie (dalej: AAN), Prezydium Rady Ministrów, cz. II, sygn. 76, b.p.a. Pismo kierownika MSW do Komisji Urzędniczej Państwa Polskiego, Warszawa 15 III 1918 r.; Z Komisji Urzędniczej, Monitor Polski 1918, nr 40, s. 3.

19 O terminologii dotyczącej pierwszych miesięcy administracji por.: J. Mierzwa, Starostowie..., s. $35-37$.

20 Z. Słomiński, Zapiski i wspomnienia z czasów pierwszego Komisariatu Rządu Polskiego w Radomiu od dnia 2/XI 1918 roku do dnia 1/III 1919 roku, Lublin 1922, s. 69. Władze zapowiadały również wprowa- 
wodował, że kwestia, w jaki sposób ten czy ów starosta będzie się wyróżniał, w istocie zależała od jego indywidualnej fantazji, a ta bywała czasami bujna. Pierwszy grójecki komisarz ludowy tak wspominał relację ministra spraw wewnętrznych Stanisława Wojciechowskiego ze spotkania z jego następcą:

Wojciechowski na mój widok zaczyna się głośno śmiać „Ależ Wy macie komisarza!” i mówi,
jak to na konferencji z komisarzami pod piecem ujrzał wysokiego brodatego mocno łysawego
obywatela z trudem walczącego z morzącym go snem, a już w podziw wprowadziła Ministra długa
szpada przetknięta przez dziurkę w marynarce mocno podniszczonej. Ponieważ ów obywatel,
wychodząc z sali, musiał przejść obok Ministra, zapytany przezeń, kto jest zacz, odpowiedział, iż
jest komisarzem grójeckim, „A po co ta szpada?” - dla powagi urzędu, odrzekł komisarz ${ }^{21}$.

Podobne, mniej lub bardziej kuriozalne przypadki stawały się coraz rzadsze wraz z zastępowaniem na stanowiskach starostów przedstawicieli miejscowej, szeroko rozumianej elity przez zawodowych urzędników, głównie zresztą proweniencji galicyjskiej. Niemniej kwestia tego, czy przyznawać urzędnikom administracji ogólnej prawo do noszenia umundurowania, nadal pozostawała aktualna, tym bardziej że równocześnie, jak wspomniano, uprawnieniem takim dysponowali urzędnicy najpierw ZCZW, a następnie ZTPiE.

Kluczem do rozwiązania tego problemu miała być ustawa o państwowej służbie cywilnej z 17 lutego 1922 r., to bowiem prawo urzędnicze powinno w sposób całościowy uregulować kwestie związane z funkcjonowaniem aparatu administracyjnego. Artykuł 35 tejże ustawy stanowił, że ,urzędnik ma prawo do noszenia munduru lub odznak służbowych, odpowiadających działowi zarządu państwowego i piastowanemu stopniowi służbowemu, o ile mundur lub odznaki służbowe wprowadzone zostaną specjalnymi przepisami" "22. Sprawa oczywiście nie wymagała natychmiastowego rozstrzygnięcia, ale ustawa otworzyła taką możliwość i poszczególne działy administracji zaczęły z niej korzystać. Jeszcze w tym samym roku ukazało się rozporządzenie regulujące zasady umundurowania funkcjonariuszy polskiej marynarki handlowej²3. Cztery lata później rozporządzeniem RM określono zasady umundurowania urzędników służby dyplomatycznej i konsularnej2 ${ }^{24}$. W 1929 r. w tym samym trybie rozstrzygnięto kwestie umundurowania urzędników celnych oraz nadzoru nad rybołówstwem morskim ${ }^{25}$. W latach 30 . XX w. określono również jednolite dla całego kraju zasady umundurowania funkcjonariuszy administracji leśnej i służby drogowej, poborców skarbowych, urzędników władz górniczych oraz kontroli skarbowej i komorników ${ }^{26}$.

dzenie dla wszystkich urzędników administracji ogólnej jako odznak czapek; Kronika, „Czas” 21 I 1919, nr 15 , s. 1 .

${ }_{21}$ Zakład Narodowy im. Ossolińskich we Wrocławiu, Dział Rękopisów, S. Czekanowski, Roczniki dtugiego żywota mego, sygn. 13258/II, t. 3D, k. 37-38.

22 Dz.U.R.P. z 1922 r. Nr 21, poz. 164.

23 Dz.U.R.P. z 1922 r. Nr 41, poz. 348.

24 Dz.U.R.P. 1926 r. Nr 33, poz. 200. Regulacje te jeszcze kilkakrotnie do 1939 r. zmieniono, abstrahując od tego, że nie były, ze względów finansowych, stosowane szczególnie konsekwentnie. P. Łossowski, Dyplomacja polska 1918-1939, Warszawa 2001, s. 161-163; R. Tarnogórski, Stużba dyplomatyczna w II Rzeczypospolitej, „Biuletyn Polskiego Instytutu Spraw Międzynarodowych” 2002, nr 48, s. 489-490.

25 Dz.U.R.P. 1929 r. Nr 52, poz. 420; Dz.U.R.P. 1929 r. Nr 82, poz. 611.

26 Dz.U.R.P. 1930 r. Nr 25, poz. 222; Dz.U.R.P. 1930 r. Nr 28, poz. 248; Dz.U.R.P. 1931 r. Nr 21, poz. 124; L.S. Pręcikowski, Ludzie lasu i ich mundur. Zarys dziejów narodowego munduru leśnego na tle rozwoju 
Omawianym regulacjom w innych działach administracji państwowej towarzyszyła dyskusja nad wprowadzeniem mundurów w administracji ogólnej - z tego tytułu w 1923 r. Ministerstwo Spraw Wewnętrznych rozesłało do podległych jednostek pytanie $^{27}$. Rezultaty tych debat nie są znane, niemniej można podejrzewać, że głównym czynnikiem stojącym na drodze do rozstrzygnięcia kwestii mundurów dla wojewodów czy starostów były problemy budżetowe. Pięć lat później, w styczniu 1928 r., Prezydium Rady Ministrów poinformowało ministra spraw wewnętrznych, że ostateczna decyzja w kwestii umundurowania administracji ogólnej zapadnie po generalnej rewizji ustawy urzędniczej. Warto jednak w kontekście momentu, w którym wspomniana dyskusja była toczona, zwrócić uwagę na to, że w zasadzie nie zmieniły się argumenty przemawiające za wprowadzeniem umundurowania w administracji. Podnoszono, że szczególnie przydatne są one funkcjonariuszom mającym bezpośredni kontakt z ludnością, zwłaszcza w służbie zewnętrznej. Chodziło przede wszystkim o przyjmowanie interesantów, wyjazdy w teren, dysponowanie Policją Państwową w czasie rozruchów lub zbiegowisk oraz w związku ze współdziałaniem $\mathrm{z}$ formacjami umundurowanymi, takimi jak wojsko, KOP czy Straż Graniczna. W ocenie władz mundur miał wzmocnić autorytet urzędnika, ułatwić wykonywanie władzy, a także chronić go. Stąd też, ze względu na posiadane kompetencje i szerszy kontakt z obywatelami urzędników administracji ogólnej I instancji, problem dotyczył przede wszystkim aparatu starościńskiego. Dodajmy, że dodatkową presję, by umundurowanie jednak wprowadzić, wywierało rosnące po przewrocie majowym grono zwalnianych ze służby czynnej oficerów. Przyzwyczajeni do służby wojskowej bardzo niechętnie żegnali się z mundurem lub wręcz tego nie czynili, gdyż MSW notowało przypadki, gdy oficerowie w stanie spoczynku - pełniąc obowiązki w administracji ogólnej lub samorządowej - nosili mundury z wojska. Oczywiście tego typu praktyki były zakazane ${ }^{28}$.

Mimo stabilizacji administracji państwowej zdarzały się przypadki, jak ów w Kielcach w maju 1932 r., gdy miejscowy starosta skarżył się, że mimo półrocznego pobytu miejscowi funkcjonariusze Policji Państwowej nie raczyli go poznać, w związku z czym nie oddają mu, bądź co bądź przełożonemu, honorów (zarówno w czasie służby, jak i po niej). W reakcji na to komendant powiatowy PP zrugał podwładnych in corpore i nakazał:

[...] wobec powyższego polecam w ciągu 2 dni nadesłać mi wykaz szeregowych, którzy dotychczas nie znają Pana Starosty Powiatowego oraz delegować tych szeregowych w najbliższych dniach, na własny koszt, do Komendy Powiatowej celem przedstawienia ich Panu Staroście w myśl zarządzenia mojego z dnia 1 VI b.r. ${ }^{29}$.

gospodarstwa leśnego w Polsce od początku XIX wieku po czasy wspótczesne, Warszawa 2006, s. 71-109. Do umundurowanych funkcjonariuszy międzywojennej administracji państwowej należy również zaliczyć m.in. kolejarzy, pocztowców, strażaków, a także pracowników służb komunalnych. Por. J. Rutkiewicz, Polski mundur dozwolony przez okupantów w latach 1939-1945, „Arsenał Poznański” 1994, nr 2, s. 1-17.

27 Archiwum Państwowe w Bydgoszczy, Starostwo Powiatowe Sępoleńskie, sygn. 27, s. 221, Pismo okólne MSW z dn. 23 VIII 1923 r. w sprawie umundurowania urzędników państwowych.

28 Dz.U.M.S.W. z 1929 r. Nr 17, poz. 358; Dz.U.M.S.W. z 1932 r. Nr 2, poz. 21. Podobnie zresztą minister Składkowski zakazywał zwracania się do siebie „,panie generale” w trakcie piastowania teki ministra spraw wewnętrznych.

29 AP Kielce, Starostwo Powiatowe Kieleckie, sygn. 984, s. 23-24.

Artykuły - Articles 
Jednocześnie zapowiedział pociąganie winnych zaniedbania do odpowiedzialności dyscyplinarnej ${ }^{30}$.

Dodać należy, że istotną motywacją, dla której urzędnicy opowiadali się za wprowadzeniem mundurów, był również kontekst finansowy. $\mathrm{W}$ ich bowiem zamyśle wprowadzenie uniformów służbowych, połączone z wprowadzeniem świadczenia mundurowego, powodowałoby, że funkcjonariusze administracji ogólnej nie musieliby stawiać się w pracy w garniturach. Wątpliwości te dotyczyły przede wszystkim urzędników referendarskich, załatwiających merytorycznie sprawy wpływające do urzędu. Funkcjonariusze niżsi, pełniący służbę zewnętrzną w starostwach i urzędach wojewódzkich - czyli przede wszystkim woźni, posłańcy i gońcy - byli natomiast zobowiązani do noszenia w czasie służby mundurów z granatowego sukna oraz czapki angielskiej ${ }^{31}$, również granatowej, z czerwonymi wypustkami. Mimo walki z deficytem budżetowym rząd zdecydował się pod koniec 1925 r. przyznać im dofinansowanie w wysokości 75\% wartości munduru. Zgodnie z okólnikiem MSW z 15 I 1927 r. funkcjonariusz miał prawo do nowej kurtki, spodni i czapki raz w roku, natomiast w przypadku płaszcza zakup był dofinansowywany przez państwo raz na trzy lata ${ }^{32}$. Regulacja została utrzymana do końca II Rzeczypospolitej, choć na początku lat 30. podjęto działania zmierzające do ujednolicenia wyglądu mundurów dla funkcjonariuszy niższych, dotychczas nieco zróżnicowanych w zależności od województwa ${ }^{33}$.

Wydaje się, że podstawową przeszkodą do uregulowania zagadnienia umundurowania urzędników referendarskich w Polsce międzywojennej był, jak zwykle, brak pieniędzy, i to w dwojakim znaczeniu. Brakowało ich bowiem w budżecie państwa, ale także w warunkach wielkiego kryzysu trudno było obciążać urzędników kosztami finansowania umundurowania. A zatem dyskusja na temat wprowadzenia jednolitych uniformów dla urzędników starostw i urzędów wojewódzkich w pierwszej poł. lat 30., o ile w ogóle prowadzona, miała charakter czysto teoretyczny, a w wymiarze praktycznym ograniczono się jedynie do utrzymania dotychczasowych rozwiązań, tj. mundurów dla funkcjonariuszy niższych. Na zmiany w tym zakresie przyszedł czas od $1935 \mathrm{r}$. Poprawa koniunktury gospodarczej, a co za tym idzie, i sytuacji budżetowej państwa, spowodowała, że także i w tej sferze przyszedł czas na porządkowanie państwa po okresie doraźnych i wymuszonych cięciami działań ${ }^{34}$. Tym samym w październiku 1935 r. zagadnienie umundurowania zostało podjęte na nowo (przez Departament Polityczny MSW), jak twierdzono - by problem rozwiązać już ostatecznie. Zwracano przy tym uwagę na to, że funkcjonariusze szeregu innych działów zarządu państwa mundury już posiadają. Warto przyjrzeć się bliżej tej dyskusji, pokazuje ona bowiem szerszy kontekst funkcjonowania polskiej administracji ogólnej w dwudziestoleciu międzywojennym.

Rozstrzygnięcie omawianego problemu na szczeblu Rady Ministrów poprzedziła ankieta rozesłana do województw celem zasięgnięcia opinii tych, których zagadnienie to bezpośrednio dotyczyło, czyli starostów jako kierowników urzędów mających w admi-

30 Ibidem.

31 Czapka angielska - rodzaj nakrycia głowy, okrągła z otokiem.

32 Dz.U.M.S.W. z 1927 r. Nr 1-2, poz. 20.

33 Dz.U.R.P. z 1925 r. Nr 126, poz. 900; Dz.U.R.P. z 1933 r. Nr 102, poz. 781.

34 Szerzej na temat wpływu poprawy sytuacji gospodarczej na politykę personalną MSW zob. J. Mierzwa, Starostowie..., s. 357-360. 
nistracji najbliższy i najczęstszy kontakt z obywatelem. Ciekawie wypadało zestawienie tych opinii z poszczególnych województw, ponieważ w zasadniczych kwestiach można je uznać za zbieżne. Starostowie postulowali wprowadzenie obligatoryjnego umundurowania przede wszystkim podczas działań związanych ze służbą zewnętrzną oraz podczas czynności reprezentacyjnych, choć pojawiały się też głosy, że umundurowanie może odgradzać urzędników od społeczeństwa; obawiano się, że projektowane zmiany mogą wywołać ostre głosy społecznego sprzeciwu. Opowiadano się również za wprowadzeniem pełnego umundurowania, a nie ograniczeniem się tylko do oznak. W ocenie ankietowanych było to rozwiązanie bardziej efektywne, znacznie utrudniające dokonanie oszustwa. Wprowadzanie mundurów dla kobiet uważano za bezprzedmiotowe (ze względu na ich niewielką liczbę w służbie) albo za „niewskazane”. Mało oryginalnie, za to zgodnie $\mathrm{z}$ duchem czasów, ustosunkowano się do tego zagadnienia w województwie warszawskim: „Odpada potrzeba umundurowania urzędników kobiet, a [należy] wprowadzić tylko obowiązek noszenia czarnych fartuchów podczas wykonywania czynności służbowych"35.

Najbardziej dyskusyjnym aspektem zagadnienia mundurowania urzędników była oczywiście kwestia, kto będzie ponosił ciężary związane z całą operacją. Większość starostów opowiedziała się za wprowadzeniem jakiegoś ekwiwalentu dla urzędników ze strony Skarbu Państwa - czy to w formie ryczałtu, 50-procentowych dopłat (na wzór rozwiązania stosowanego wobec funkcjonariuszy niższych), pożyczek czy też bezprocentowego kredytu itp. Niektórzy $z$ ankietowanych proponowali wyjście może mało sympatyczne, ale chyba bliższe potencjalnemu rozwiązaniu - „koszty wprowadzenia mundurów powinni całkowicie ponieść urzędnicy”. Warto w tym miejscu zaznaczyć, że w rozporządzeniach przygotowanych na podstawie wniosków wynikających z sondażu brakowało rozstrzygnięcia omówionej kwestii ${ }^{36}$.

Szereg uwag natury bardziej generalnej podniosło w swojej opinii Biuro Usprawnienia Administracji Prezydium Rady Ministrów. Wskazywano zatem, że wprowadzenie mundurów oznacza de facto ściślejszą dyscyplinę i upodobnienie omawianej struktury do organizacji wojskowej.

Podjęcie myśli umundurowania urzędników w chwili obecnej wypływa z dobrze odczutych prądów aktualnych i rozwoju stosunków wewnętrznych i zewnętrznych. Obrona Państwa, będąca we wszystkich państwach dominującym czynnikiem, wykracza daleko poza ramy organizacji wojska i nakłada na urzędy cywilne - przede wszystkim administracji ogólnej - niezmiernie doniosłe obowiązki. Podkreślić należy, że w interesie prac nad przygotowaniem obrony Państwa i podołania obowiązkom w razie wybuchu konfliktu leży silniejsze zdyscyplinowanie administracji ogólnej, do czego ważnym środkiem jest umundurowanie urzędników ${ }^{37}$.

Myślenie to dobitnie oddawało czas, w którym rozważano wprowadzenie uniformów. Warto dodać, że podkreślano, iż mundur nie tylko uprawnia, ale i zobowiązuje

35 Na tle podobnych głosów wyróżniał się starosta pińczowski dr Karol Winiarz opowiadający się za wypracowaniem odrębnych wzorów mundurów dla kobiet. Archiwum Państwowe w Kielcach, Urząd Wojewódzki Kielecki, sygn. 2191, s. 17, Pismo starosty pińczowskiego do wojewody kieleckiego w przedmiocie: mundury i oznaki służbowe urzędników administracji państwowej, Pińczów 24 III 1938 r.

36 AAN, MSW, dopływ-III, sygn. 775, b.p.a., Zestawienie opinii wojewodów w sprawie mundurów i oznak służbowych urzędników administracji ogólnej.

37 Ibidem. 
- umundurowani urzędnicy w zakresie zachowania się powinni być poddani surowszym rygorom niż nieumundurowani ${ }^{38}$.

Argumentów na rzecz wprowadzenia mundurów szukano także w uwarunkowaniach narodowościowych. Przyzwyczajenie społeczeństw kresowych do munduru, wynikające jeszcze z lat zaborów, powodowało, że władza polska na tym terenie była bardziej identyfikowana z policjantem niż z urzędnikiem starostwa. Mundur miał również spełniać funkcję integrującą korpus urzędniczy.

Jak stwierdzano w opinii Wydziału Narodowościowego MSW,

[...] na terenach narodowościowo mieszanych pracuje pewien odsetek urzędników narodowości niepolskiej. Ich sytuacja jest dość uciążliwa, ponieważ bez względu na stopień lojalności ciąży wciąż na nich piętno przynależności do narodu niepolskiego, co ze strony Polaków będzie stale akcentowane. Mundur tymczasem nada każdemu jednostronny charakter urzędnika państwowego przede wszystkim ${ }^{39}$.

Rezultatem konsultacji były projekty rozporządzeń RM oraz MSW o umundurowaniu i oznakach służbowych urzędników administracji spraw wewnętrznych. Argumenty ministerstwa przemawiające za wprowadzeniem mundurów w zasadzie pokrywały się z wnioskami wynikającymi z ankiet starościńskich. Podnoszono przede wszystkim konieczność stosowania munduru (lub specjalnego stroju) podczas służby zewnętrznej (spotkania $\mathrm{z}$ interesantami, wyjazdy w teren, dysponowanie jednostkami PP w czasie rozruchów). W ocenie władz wprowadzenie munduru (nawet w postaci odrębnego stroju, jak w przypadku sędziów czy prokuratorów) podnosiło powagę urzędu i stanowiło dodatkową ochronę dla noszącego go. Pojawiały się tu także pewne argumenty natury praktycznej, wynikające z niedostatecznego uposażenia urzędników, niepozwalającego im na zakup większej liczby garniturów jakości adekwatnej do warunków służby zewnętrznej. Co ciekawe, sprawę wprowadzenia mundurów uznawano za pilną, dlatego też proponowano tymczasowe rozstrzygnięcie w postaci wprowadzenia obowiązku częściowego umundurowania (czapka ewentualnie kurtka) dla tej kategorii urzędników, która w największym stopniu miała kontakt z obywatelami, to znaczy funkcjonariuszy starostw powiatowych. W kwestii technicznej zamierzano wykorzystać projekty mundurów przygotowane na żądanie Prezydium Rady Ministrów jeszcze w 1926 r. przez Departament Sztuki MWRiOP ${ }^{40}$.

Zgodnie z projektem rozporządzenia Rady Ministrów uniformy urzędników administracji ogólnej miały być koloru ciemnogranatowego ${ }^{41}$, z guzikami koloru złotego, zawierającymi wypukły wizerunek orła państwowego. Na umundurowanie miały się składać: kurtka, spodnie, płaszcz oraz czapka angielska z czarnym daszkiem. Urzędnicy na patkach ${ }^{42}$ kurtki i płaszcza mieli nosić oznaki związane z posiadaną przez nich grupą uposażenia. Na górnym brzegu patki mundurów starostów (powiatowych, grodzkich,

${ }^{38}$ AAN, MSW, dopływ-III, sygn. 775, b.p.a., Biuro Usprawnienia Administracji.

39 AAN, MSW, dopływ-III, sygn. 775, b.p.a., Notatka w sprawie mundurów i oznak służbowych urzędników administracji ogólnej, Warszawa 1 XII 1937 r.

${ }^{40}$ AAN, MSW, dopływ-III, sygn. 775, b.p.a., Pismo dyrektora Gabinetu MSW R. Hausnera do Prezydium Rady Ministrów w przedmiocie: rozporządzenie RM i rozporządzenie MSW o umundurowaniu i oznakach służbowych urzędników administracji wewnętrznej, Warszawa 3 IV 1939 r.

${ }_{41}$ Pierwotnie planowano kolor ciemnozielony, który jednak był już używany przez Straż Graniczną.

42 Patka - oznaka naszywana na kołnierzu kurtki mundurowej. 
starosty morskiego i komisarza rządu w Gdyni) oraz wojewodów dodatkowo miał być umieszczony haftowany srebrny orzełek. Przewidywano możliwość przystosowania mundurów do warunków zimowych, zastępowania płaszcza mundurowego cywilnym, jak również noszenia w zimie czapek cywilnych oraz futer.

Wyrazem pewnej niekonsekwencji były przepisy $§ 7$, zgodnie z którymi autorzy projektu nie zamierzali przyznawać mundurów pracownikom kontraktowym. Pojawia się w związku z tym pytanie, czy umundurowani byliby urzędnicy referendarscy lub kierownicy starostw, których stosunek pracy regulowały umowy cywilnoprawne (a byli tacy). Inną niekonsekwencją było przyznanie praktykantom I kategorii mundurów X grupy uposażenia, a praktykantom II kategorii - XI grupy uposażenia. W §7 zastrzeżono jednak, że przepisy o umundurowaniu i odznakach służbowych nie mają zastosowania do... praktykantów. Pojawiające się tego typu sprzeczności dowodzą, że projekt rozporządzenia był w lipcu 1939 r. daleki od spójności. Inny problemem było powiązanie dystynkcji na patkach kurtek i płaszczy z grupami uposażenia, a nie z piastowanymi stanowiskami. Na podstawie rozporządzenia Prezydenta RP z 7 X 1932 r. zerwano formalny związek między wynagrodzeniem a tytułem służbowym (choć i w późniejszym okresie mimowolnie wiązano te dwa zagadnienia) $)^{43}$. Teoretycznie zatem było możliwe piastowanie stanowiska starosty przez urzędnika VIII grupy uposażenia. Odniesienie w dystynkcjach do wynagrodzenia, a nie do stanowiska mogło więc być dla osób trzecich mylące.

Omawiana dyskusja była przejawem najbardziej zaawansowanych prac nad wprowadzeniem umundurowania dla urzędników administracji ogólnej. Zgodnie z projektem urzędnicy starostw mieli obowiązek (i prawo zarazem) noszenia mundurów w czasie urzędowania w biurze i poza nim. W szczególnych przypadkach urzędnik mógł być zwolniony z konieczności noszenia munduru na podstawie decyzji starosty, jeżeli leżało to w interesie służby. Zakazano noszenia mundurów i oznak służbowych poza służbą, przewidziano natomiast mundury dla kobiet - urzędników starostw. W rozporządzeniu założono również istnienie rocznego okresu przejściowego. W jego trakcie dopuszczano występowanie przez funkcjonariuszy w ubiorze cywilnym podczas czynności urzędowych, co nie dotyczyło jednak starostów, wicestarostów, referentów bezpieczeństwa i spraw wojskowych ${ }^{44}$.

Tak zarysowane projekty rozporządzenia RM oraz rozporządzenia MSW podlegały jeszcze konsultacjom na szczeblu rządowym. Trwały one, jak wspomniano, co najmniej do lipca 1939 r., stąd też ostatecznie do wprowadzenia mundurów dla urzędników administracji ogólnej w okresie II Rzeczypospolitej nie doszło. Mimo wszystko całokształt dyskusji sporo nam mówi nie tylko o typologii munduru, ale też (może przede wszystkim) o elementach związanych z funkcjonowaniem międzywojennej administracji:

1) Zarówno w odniesieniu do stanów przejściowych związanych z funkcjonowaniem administracji ZCZW i ZTPiE, jak i do aparatu urzędniczego działającego w warunkach ustabilizowanego państwa mundur funkcjonariusza państwowego miał spełniać dokładnie takie same funkcje jak mundur wojskowy. Wiesław i Lena Zajączkowscy w tym wręcz doszukiwali się jego definicji:

43 J. Mierzwa, Starostowie..., s. 374-375.

44 AAN, MSW, dopływ-III, sygn. 775, b.p.a., Projekt rozporządzenia MSW z dn. ... o umundurowaniu i oznakach służbowych urzędników administracji spraw wewnętrznych. 
Funkcja konstytutywna munduru to nie jego funkcja jako odzieży stosowanej w tych czy innych okolicznościach, lecz jego funkcja jako komunikatu wizualnego o wysokim stopniu kodyfikacji, w którym wykorzystano substrat ubraniowy do przekazywania informacji wojskowych o noszącej mundur osobie ${ }^{45}$.

2) Mundury były traktowane (zarówno przez funkcjonariuszy, którzy mieli je nosić, jak i przez władze centralne, odpowiedzialne za wydanie odpowiednich regulacji) jako element budujący autorytet urzędnika. Choć zdawano sobie sprawę z tego, że może to prowadzić do separacji czy wyizolowania aparatu od społeczeństwa, to wyżej stawiano konieczność zapewnienia funkcjonariuszom odpowiednich warunków służby, przede wszystkim zewnętrznej.

3) Mundur był również odzwierciedleniem kompetencji przypisanych urzędnikowi, który miał go nosić. W istocie stanowił jego swoistą ochronę. Tym można tłumaczyć przyznanie komornikom czy poborcom podatkowym prawa do munduru, ale podobnie było z urzędnikami administracji ogólnej. W związku z kompetencjami, np. w zakresie polityki karno-administracyjnej, ale także z odpowiedzialnością za stan bezpieczeństwa publicznego na podległym funkcjonariuszom terenie, wykonywanie tych uprawnień, zwłaszcza w sytuacji zaburzenia porządku, mogło się wiązać z osobistym zagrożeniem. Mundur miał pomóc zabezpieczyć ich przed tego typu zdarzeniami ${ }^{46}$. To symptomatyczne, że przed 1939 r. państwo musiało sięgać po podobne instrumenty, aby chronić swoich funkcjonariuszy ${ }^{47}$.

Podsumowując - pomysły na to, by wprowadzić umundurowanie urzędników administracji ogólnej, były wyrazem czasów, w których się pojawiały. Mimo zatem różnych zapędów, by we współczesnych rozwiązaniach w tym zakresie odwoływać się do tradycji II Rzeczypospolitej, wydaje się, że akurat w tym wypadku nie jest to fortunne, bo pojawienie się któregoś z obecnych starostów czy wojewodów w mundurach z 1926 r. dzisiaj raczej wywołałoby rozbawienie, niż wzmocniłoby jego autorytet.

45 W. i L. Zajączkowscy, Mundur wojskowy jako komunikat wizualny, „Studia do dziejów dawnego uzbrojenia i ubioru wojskowego" 2005, cz. XII, s. 43.

46 Inna rzecz, że tak jak mundur nie mógł ochronić interweniujących policjantów, tak też zdarzały się, nierzadkie wcale przypadki ataków na urzędników przy pełnej świadomości atakujących, na kogo podnoszą rękę.

47 Przypadki, gdy podczas niepokojów społecznych w II RP ginęli nawet umundurowani policjanci, nie należały do rzadkości. Por. np. P. Cichoracki, Polesie nieidylliczne. Zaburzenia porzadku publicznego w województwie poleskim w latach trzydziestych XX w. Łomianki 2007, s. 377. 


\section{Bibliografia}

\section{Źródła archiwalne}

Archiwum Akt Nowych w Warszawie, Ministerstwo Spraw Wewnętrznych, dopływ-III, sygn. 775.

Archiwum Akt Nowych w Warszawie, Prezydium Rady Ministrów, cz. II, sygn. 76.

Archiwum Państwowe w Bydgoszczy, Starostwo Powiatowe Sępoleńskie, sygn. 27.

Archiwum Państwowe w Kielcach, Starostwo Powiatowe Kieleckie, sygn. 984.

Archiwum Państwowe w Kielcach, Urząd Wojewódzki Kielecki, sygn. 2191, 2264.

Zakład Narodowy im. Ossolińskich we Wrocławiu, Dział Rękopisów, S. Czekanowski, Roczniki dtugiego żywota mego, sygn. 13258/II, t. 3D.

\section{Źródła drukowane}

Ustawa z dnia 17 lutego 1922 r. o państwowej służbie cywilnej (Dz.U.R.P. z 1922 r. Nr 21, poz. 164).

Rozporządzenie Prezydenta Ministrów z dnia 12 maja 1922 r. wydane w porozumieniu z Ministrem Przemysłu i Handlu, Ministrem Skarbu i Ministrem Spraw Wojskowych w przedmiocie umundurowania funkcjonariuszy polskiej marynarki handlowej (Dz.U.R.P. z 1922 r. Nr 41, poz. 348).

Rozporządzenie Rady Ministrów z dnia 2 grudnia 1925 r. w sprawie przyznania funkcjonariuszom niższym umundurowania za opłatą 25\% jego wartości (Dz.U.R.P. z 1925 r. Nr 126, poz. 900).

Rozporządzenie Rady Ministrów z dnia 19 lutego 1926 r. w sprawie umundurowania urzędników służby dyplomatycznej i konsularnej (Dz.U.R.P. z 1926 r. Nr 33, poz. 200).

Rozporządzenie Rady Ministrów z dnia 24 czerwca 1929 r. o umundurowaniu urzędników celnych (Dz.U.R.P. z 1929 r. Nr 52, poz. 420).

Rozporządzenie Rady Ministrów z dnia 8 listopada 1929 r. o umundurowaniu funkcjonariuszów państwowych pełniących nadzór nad rybołówstwem morskim (Dz.U.R.P. z 1929 r. Nr 82, poz. 611).

Rozporządzenie Rady Ministrów z dnia 1 marca 1930 r. o umundurowaniu i oznakach służbowych funkcjonariuszów administracji lasów państwowych (Dz.U.R.P. z 1930 r. Nr 25, poz. 222).

Rozporządzenie Ministra Skarbu z dnia 19 lutego 1930 r. o umundurowaniu sekwestratorów podatkowych mianowanych na stałe (Dz.U.R.P. z 1930 r. Nr 28, poz. 248).

Rozporządzenie Rady Ministrów z dnia 12 lutego 1931 r. o umundurowaniu i oznakach służbowych urzędników władz górniczych (Dz.U.R.P. z 1931 r. Nr 21, poz. 124).

Rozporządzenie Rady Ministrów z dnia 19 grudnia 1933 r. o zasadach zaszeregowania funkcjonarjuszów państwowych do grup uposażenia i automatycznego przechodzenia nauczycieli do wyższych grup uposażenia, o dodatkach lokalnych, funkcyjnych i służbowych oraz o umundurowaniu niższych funkcjonarjuszów państwowych (Dz.U.R.P. z 1933 r. Nr 102, poz. 781).

Rozporządzenie Ministra Spraw Wewnętrznych z dnia 14 października 1920 r. w przedmiocie umundurowania urzędników Zarządu Terenów Przyfrontowych i Etapowych, oraz zapomogi na umundurowanie (Dz.U.Z.T.P.E. z 1920 r. Nr 2, poz. 12).

Rozkaz naczelnego Wodza W. P. Z dn. 13 maja 1919 r. rozgraniczający sfery kompetencji władz wojskowych i Zarządu Cywilnego Ziem Wschodnich (Dz.U.Z.C.Z.W. z 1919 r. Nr 3, poz. 16). 
Rozkaz Naczelnego Wodza W. P. z d. 10 października r. 1919, dotyczący zmiany umundurowania funkcjonarjuszów Zarządu Cywilnego Z. W. (Dz.U.Z.C.Z.W. z 1919 r. Nr 22, poz. 226).

Rozkaz Naczelnego Wodza W. P. w przedmiocie określania kompetencji Ministra Spraw Wewnętrznych w sprawach Zarządu Tymczasowego Terenów Przyfrontowych i Etapowych, oraz rozgraniczenia kompetencji władz cywilnych i wojskowych na tych terenach (Dz.U.Z.T.P.E. z 1920 r. Nr 1, poz. 4).

Okólnik Nr. 8 z dn. 15 stycznia 1927 r. Nr. I. OB. 152/27 do Pana Wojewody (do wszystkich) Pana Komisarza Rządu na m. st. Warszaw, Pana Komendanta Głównego Pol. Państw., Departamentu V-go i Głównego Urzędu Statystycznego w sprawie czasokresu używalności munduru dla funkcjonariuszów niższych objętych rozporządzeniem Rady Ministrów z dnia 4. XI. 1925 r. (Dz.U.R.P. Nr 119, poz. 847) (Dz.U.M.S.W. z 1927 r. Nr 1-2, poz. 20).

Okólnik Nr. 241 z 4 listopada 1929 roku (OP. 12162/1-R) o noszeniu munduru przez oficerów w stanie spoczynku przy wykonywaniu obowiązków, wypływających z zajmowanych przez nich stanowisk w cywilnej służbie państwowej lub samorządowej (Dz.U.M.S.W. z 1929 r. Nr 17, poz. 358).

Pismo Nr. Pers. 705/1 dnia 23 stycznia 1932 r. o zakazie noszenia przez oficerów w stanie spoczynku munduru podczas pełnienia obowiązków funkcjonarjusza administracji cywilnej lub pracownika instytucji samorządowej (Dz.U.M.S.W. z 1932 r. Nr 2, poz. 21).

Zarządzenie (13451/224) Komisarza Generalnego Ziem Wschodnich, dotyczące zmiany umundurowania urzędników Zarządu Cywilnego Ziem Wschodnich (Dz.U. Z.C.Z.W. z 1919 r. Nr 23, poz. 236).

Kronika, „Czas”, 21 I 1919, nr 15.

Z Komisji Urzędniczej, Monitor Polski, $1918 \mathrm{nr} 40$.

\section{Opracowania}

Cichoracki P., Polesie nieidylliczne. Zaburzenia porządku publicznego w województwie poleskim w latach trzydziestych XX w., Łomianki 2007.

Gierowska-Kałłaur J., Zarząd Cywilny Ziem Wschodnich (19 lutego 1919 - 9 września 1920), Warszawa 2003.

Kostankiewicz A., Umundurowanie i uzbrojenie Policji Państwowej 1919-1939, „Zeszyt Naukowy Muzeum Wojska” 2000, nr 13.

Kostankiewicz A., Umundurowanie i uzbrojenie polskiej Straży Granicznej (1928-1939), „Studia do dziejów dawnego uzbrojenia i ubioru wojskowego" 2011, cz. XIII.

Kostankiewicz A., Umundurowanie i uzbrojenie Straży Więziennej II RP (1924-1939) [w:] Z dziejów więzienia w Lublinie, red. T. Radzik, Lublin 2007.

Kozyra W., Polityka administracyjna władz polskich na Ziemiach Wschodnich Rzeczypospolitej Polskiej w latach 1918-1926, „Annales UMCS. Sec. F (Historia)” 2005, t. LIX.

Kroczyński H., Mundur Armii Wielkopolskiej. Ze zbiorów Muzeum Oręża Polskiego w Kołobrzegu, Kołobrzeg 2008.

Lietz W., Umundurowanie lekarzy weterynarii w latach 1914-1939 [w:] Wybitni lekarze weterynaryjni na przestrzeni dziejów w świecie $i$ w Polsce. Historia zawodu lekarsko-weterynaryjnego, zainteresowania pozazawodowe lekarzy weterynaryjnych, Sesja naukowa z udziałem gości zagranicznych, Wrocław-Kobyla Góra, 20-22 czerwca 2003, oprac. J. Króliński.

Litwiński R., Korpus Policji w II Rzeczypospolitej. Stużba i życie prywatne, Lublin 2010.

Łossowski P., Dyplomacja polska 1918-1939, Warszawa 2001.

Maisel W., Archeologia prawna Polski, Warszawa-Poznań 1982.

Mierzwa J., Starostowie Polski międzywojennej. Portret zbiorowy, Kraków 2012. 
Pawlak K., Więziennictwo polskie w latach 1918-1939, Kalisz 1995.

Pręcikowski L.S., Ludzie lasu i ich mundur. Zarys dziejów narodowego munduru leśnego na tle rozwoju gospodarstwa leśnego w Polsce od początku XIX wieku po czasy wspótczesne, Warszawa 2006.

Rezler M., Mundur wielkopolski w latach 1918-1919, Kościan 1973.

Rutkiewicz J., Polski mundur dozwolony przez okupantów w latach 1939-1945, „Arsenał Poznański" 1994, nr 2.

Rutkiewicz J., Umundurowanie KOP [w:] J. Prochwicz, A. Kostankiewicz, J. Rutkiewicz, Korpus Ochrony Pogranicza 1924-1939, Warszawa 2006.

Skorek A., Umundurowanie funkcjonariuszy Straży Celnej (1926), „Grot. Zeszyty Historyczne poświęcone historii wojska i walk o niepodległość" 2003, nr 16.

Słomiński Z., Zapiski i wspomnienia z czasów pierwszego Komisariatu Rządu Polskiego w Radomiu od dnia 2/XI 1918 roku do dnia 1/III 1919 roku, Lublin 1922.

Smoliński A., Mundur i barwy jazdy dywizyjnej i strzelców konnych Wojska Polskiego. Lata 1919-1939, Grajewo 2012.

Tarnogórski R., Stużba dyplomatyczna w II Rzeczypospolitej, „Biuletyn Polskiego Instytutu Spraw Międzynarodowych" 2002, nr 48.

Wielecki H., Polski mundur wojskowy 1918-1939, Warszawa 1995.

Zajączkowscy W. i L., Mundur wojskowy jako komunikat wizualny, „Studia do dziejów dawnego uzbrojenia i ubioru wojskowego" 2005, cz. XII. 


\section{ANVEKS}

Projekty mundurów urzędników administracji ogólnej przygotowane przez Departament Sztuki Ministerstwa Wyznań Religijnych i Oświecenia Publicznego, 1926 r. (Archiwum Akt Nowych w Warszawie, Ministerstwo Spraw Wewnętrznych, dopływ - III, sygn. 775) 


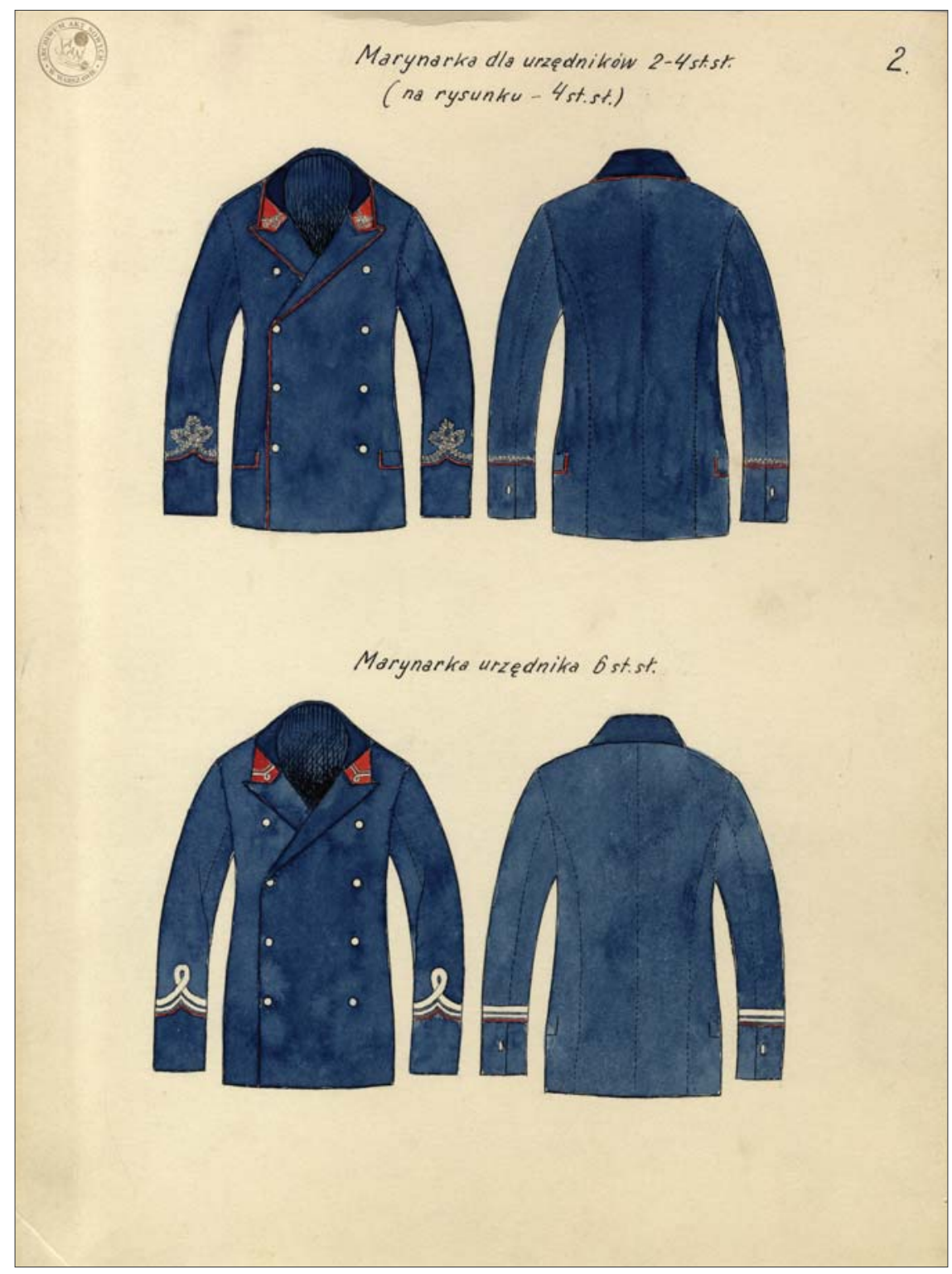




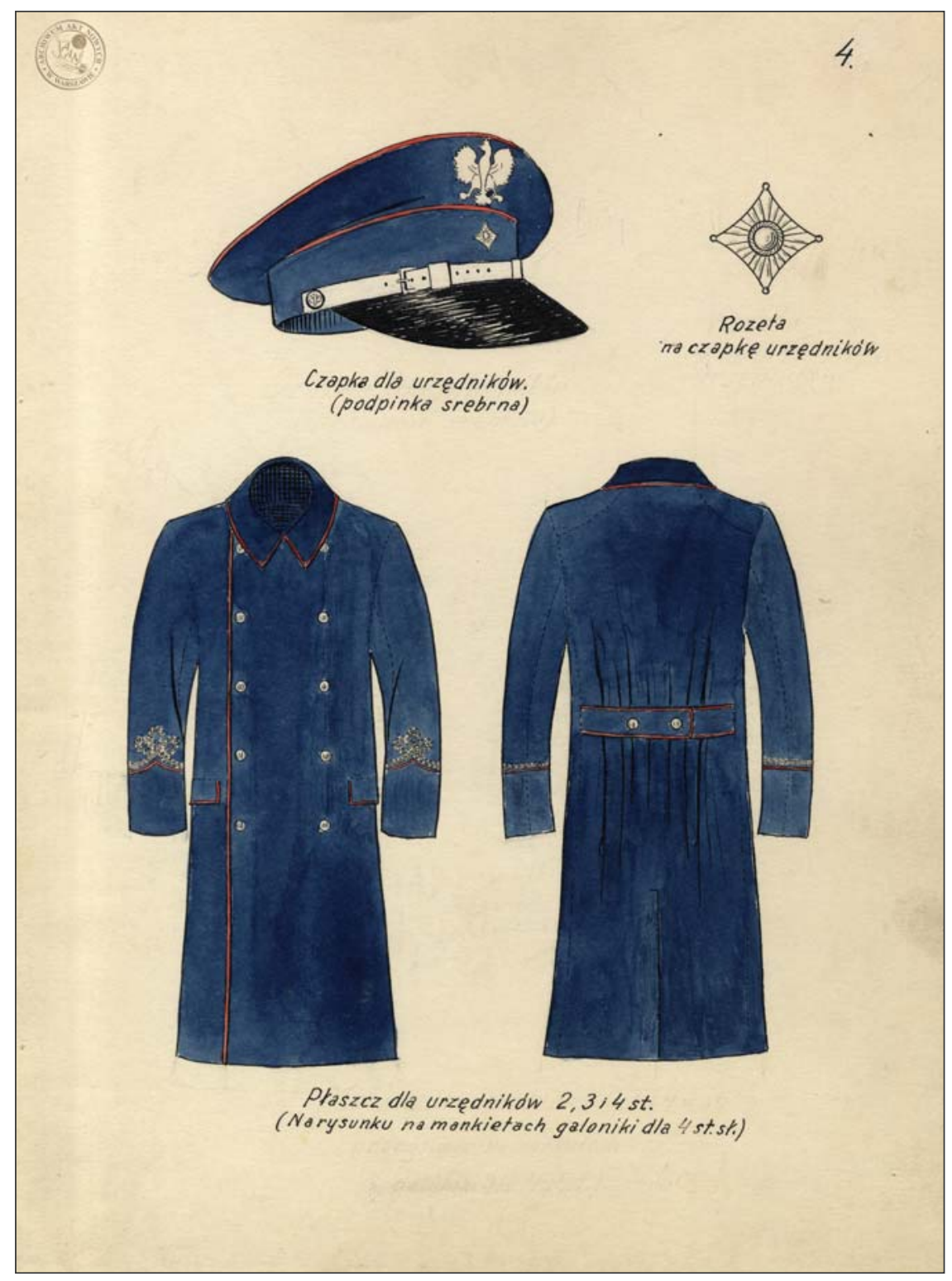




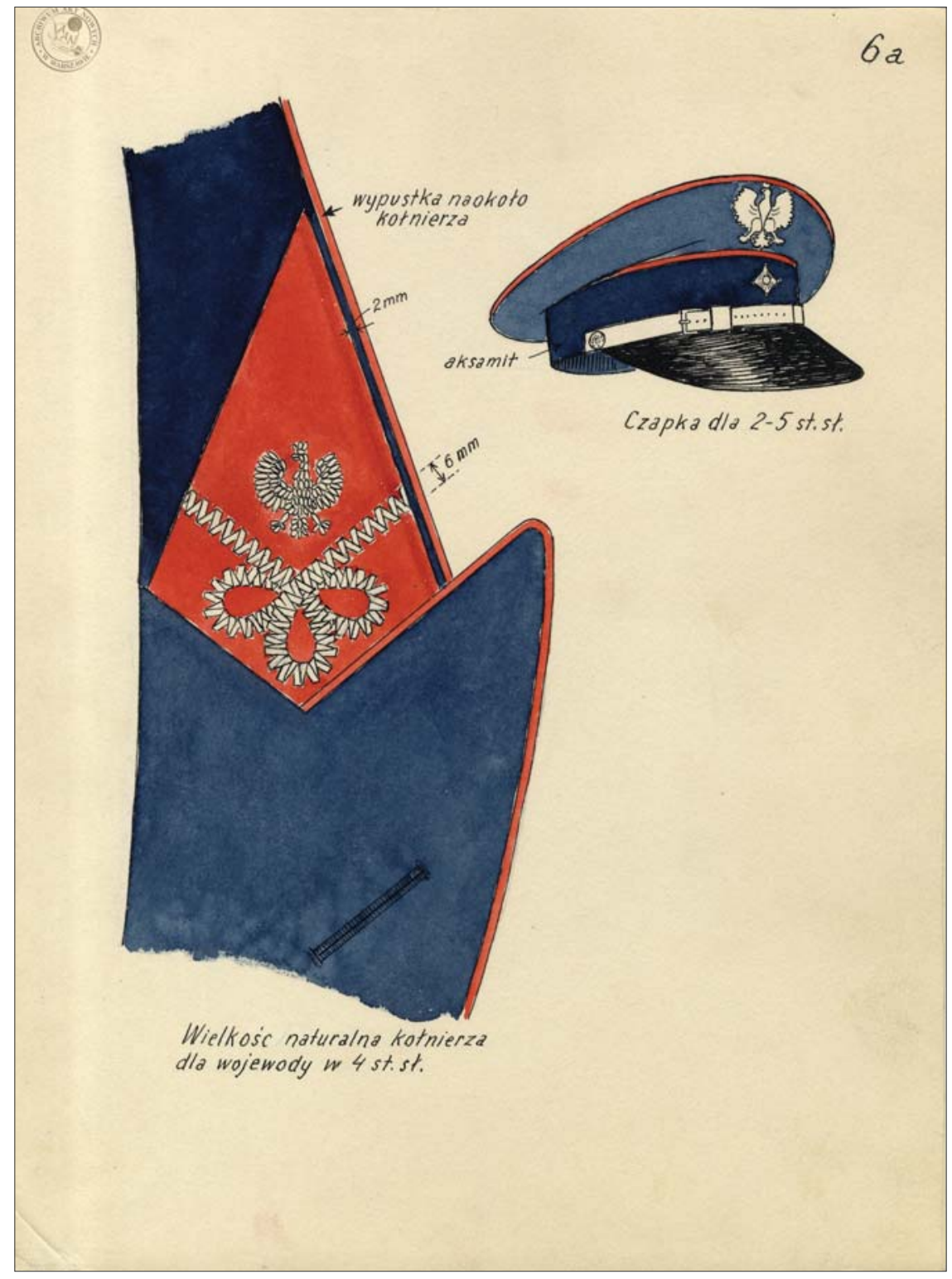




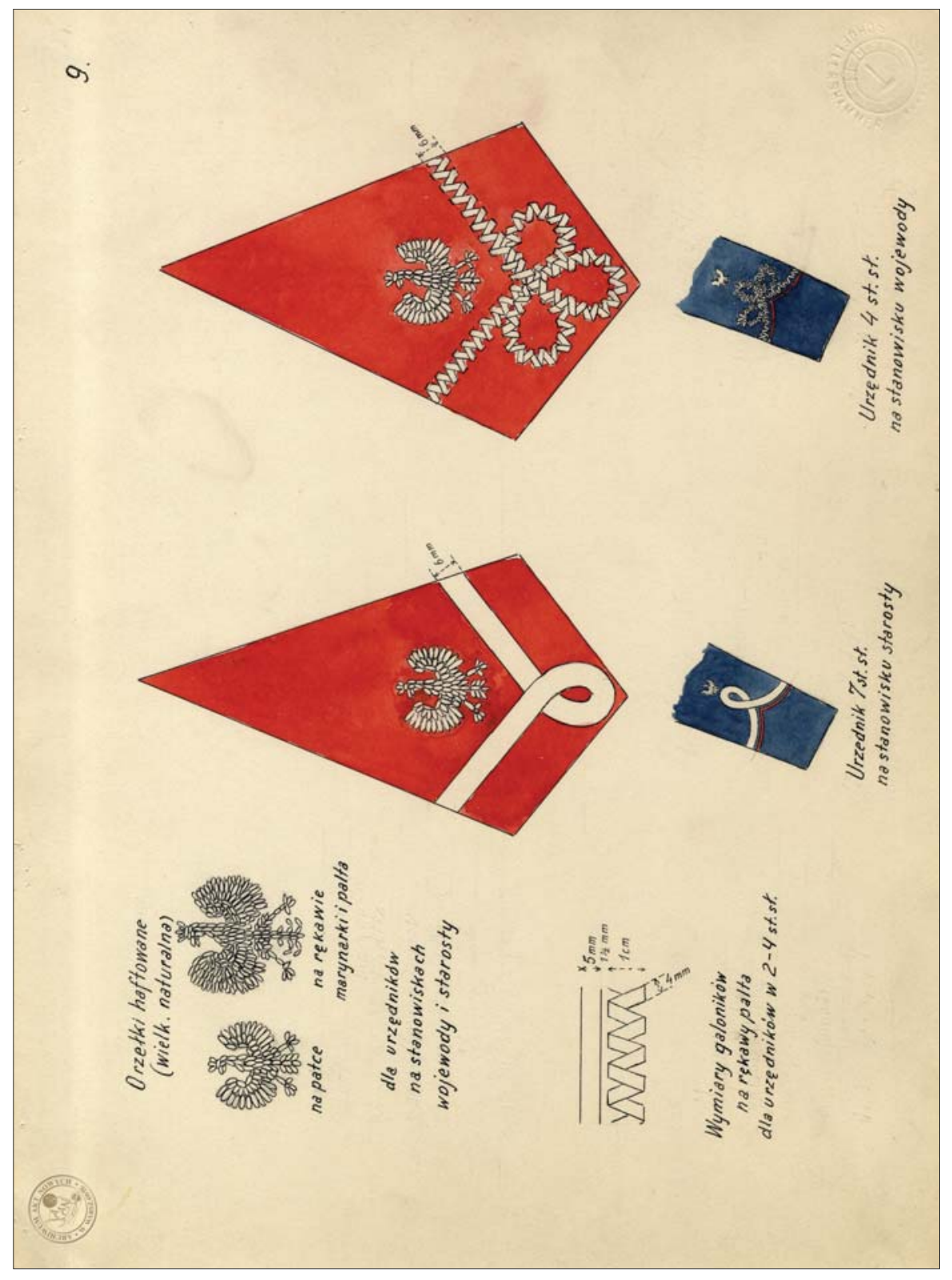




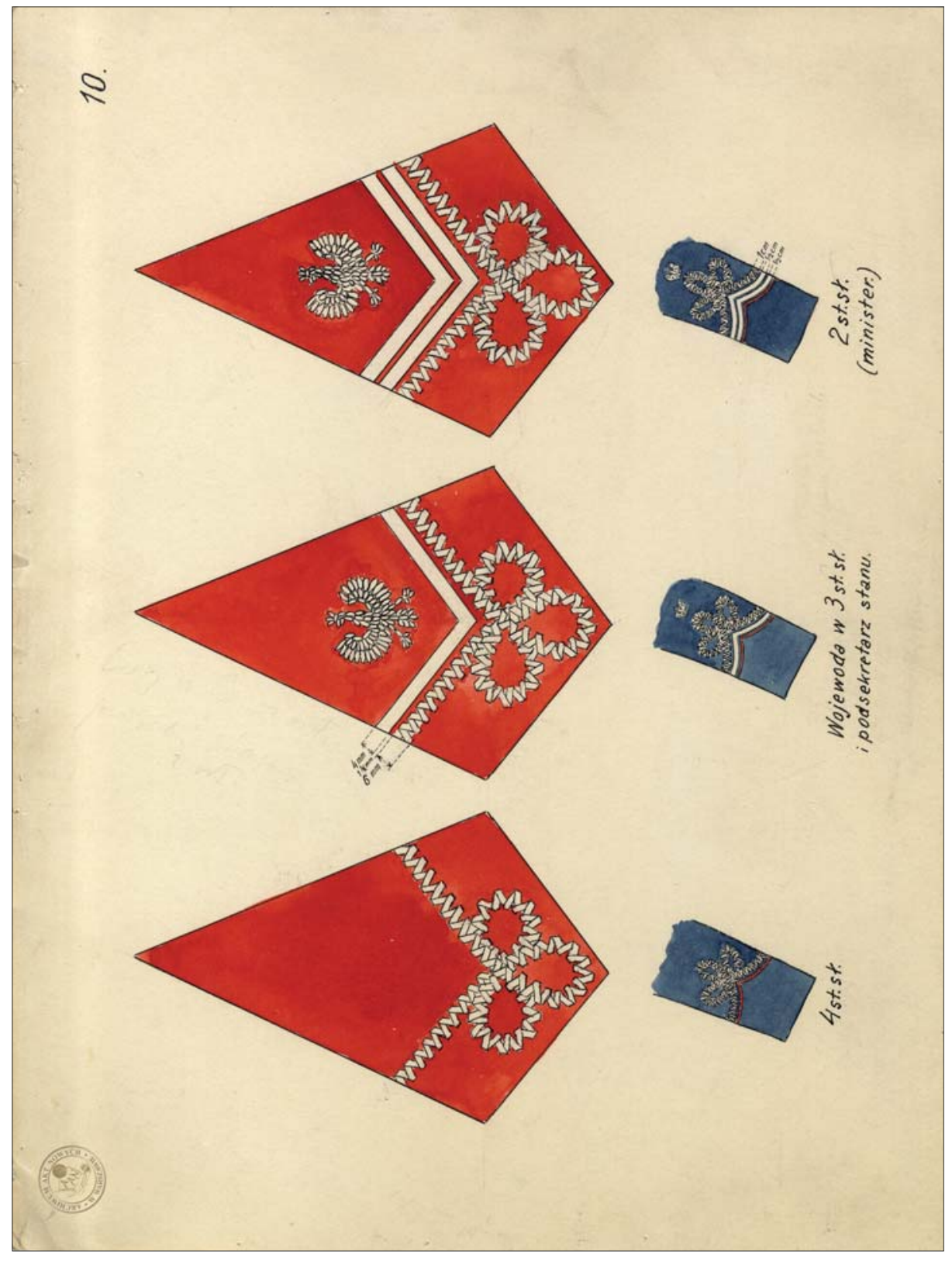




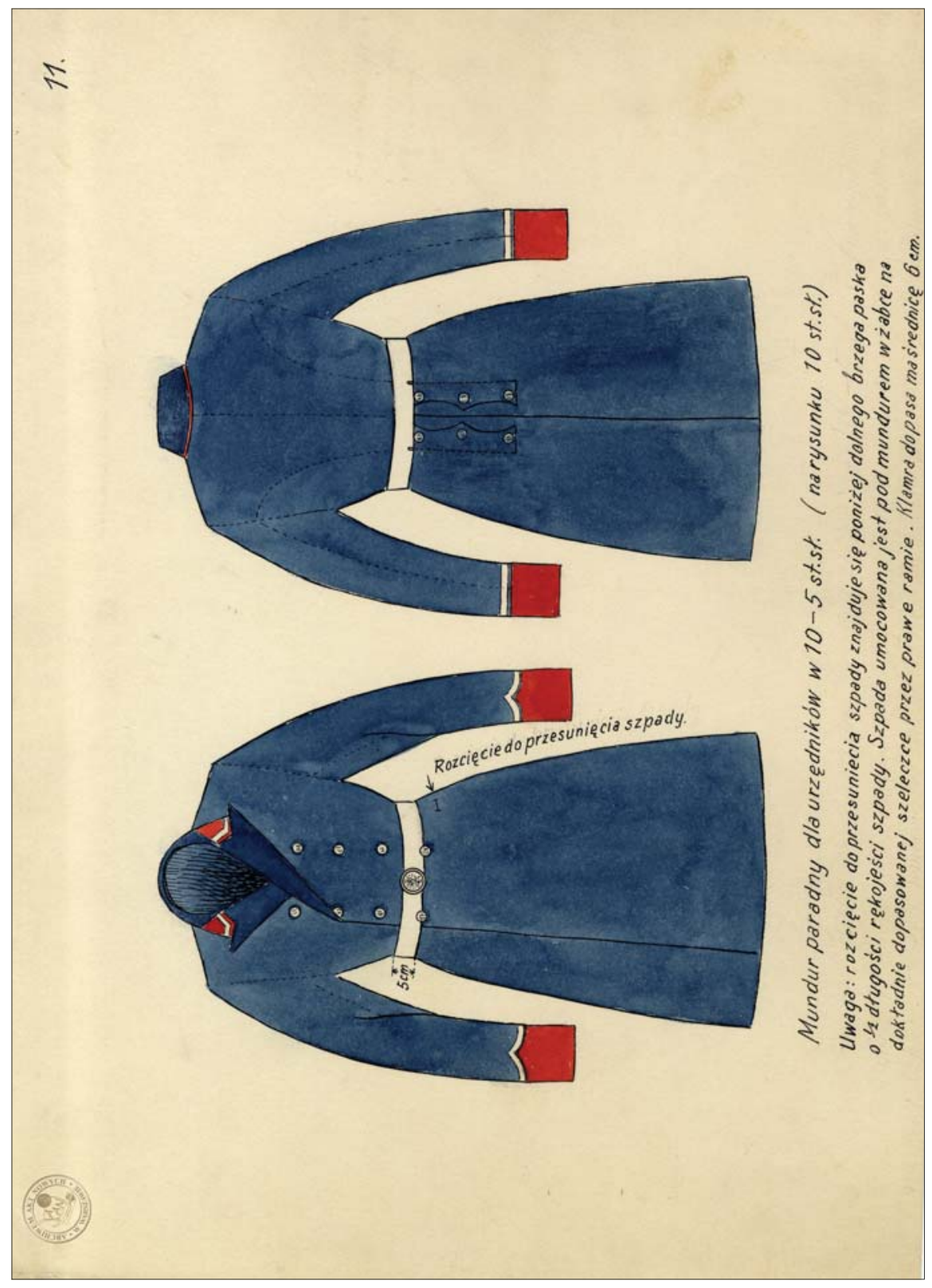

